Јасмина У. Клеменовић *

UDK: $37.018 .1 / .26$

Филозофски факултет

37.064 .1

Универзитет у Новом Саду

Наташа Цвијановић**

DOI: $10.19090 / \mathrm{gff} .2017 .2 .209-224$

Министарство просвјете и културе

Оригинални научни рад

Републике Српске Бања Лука, БиХ

\title{
ИСПИТИВАЊЕ СПОНТАНОГ УКЉУЧИВАЊА РОДИТЕЉА У ОБРАЗОВАЊЕ ДЕЦЕ НА ПОЧЕТКУ ШКОЛОВАЊА***
}

Рад је усмерен на испитивање активности којима се родитељи спонтано укључују у образовање своје деце и њиховог доприноса напредовању ученика на почетку школовања. Истраживањем је обухваћено 1439 ученика првог разреда из 18 школа Републике Српске и исто толико њихових родитеља. Анкетирањем родитеља испитивана је заступљеност различитих типова активности у кругу породице и у комуникацији са школом, док је напредовање ученика на почетку школовања праћено скалом процене остварености исхода учења и развоја у четири развојне сфере. Показало се да је највише спонтаних активности којима се родитељи укључују усмерено на осамостаљивање деце и подршку њиховом моторичком развоју, а потом и на савладавање школских задатака и обавеза. Притом је укљученост мајки у активности оријентисане на школу у позитивној вези са напредовањем ученика у сфери интелектуалног развоја, као и развоја говора, комуникације и стваралаштва, док је укљученост очева у моторичке активности и осамостањивање деце у позитивној корелацији са напредовањем ученика у свим развојним сферама. Налази указују на важност јачања свести родитеља о значају њиховог укључивања у образовање деце кроз различите типове активности већ од најранијег детињства и посебно током првих година школовања, у чему важну улогу имају све васпитно-образовне установе.

Кључне речи: укључивање родитеља у образовање деце, подршка учењу детета код куће, сарадња породице и школе, напредовање ученика на почетку школовања.

\section{УВОД}

Иако је поставка о значају укључивања породице/родитеља у образовање деце већ деценијама уназад незаобилазна компонента образовних

\footnotetext{
*jasminaklemenovic.uns@gmail.com

** natasa.c09@gmail.com

*** The paper was written within the scientific and research Project "Pedagogical Pluralism as the Basis of the Education Strategy", supported by the Ministry of Education, Science and Technological Development of the Republic of Serbia.
} 
политика у већини земаља света, тек деведесетих година прошлог века започело је опсежније систематско праћење и проучавање ефеката ових активности на понашање деце, њихово учење и напредовање током школовања. Већ након првих већих студија наметнуо се општи закључак да „укључивање родитеља у образовање деце може значајно допринети побољшању резултата учења“ (Drake, 2000: 34) будући да омогућава успешније социо-емоционално прилагођавање детета захтевима школе и да подупире постизање бољег академског успеха на почетку школовања (Carter, 2002), али и касније (Simon, 2001). Установљена је позитивна веза између родитељске укључености у образовање и дечјег развоја (Fantuzzo et al., 2000; Collins et al., 2000), те постигнућа детета на почетку школовања (Davis-Kean, 2005).

У новије време, опште прихваћана је поставка да школе, заједнице и породице/ родитељи морају да сарађују и заједнички раде на побољшању искуства учења све деце (Carter, 2002; Klemenović, 2014). Отуда су током последњих деценија широм света интензивно развијани и испробавани различити модели и разноврсни програми подршке јачању ових односа што је довело до великог броја истраживања ефеката интервенција усмерених на побољшање учешћа родитеља, упоредо са истраживањима којима се испитује утицај спонтаног укључивања родитеља у образовање деце на дечји развој, учење и понашање у школи. Док су интервентни програми подршке укључивању родитеља, по правилу иницирани 'одозго' како би се подстакло и осигурало учешће родитеља у образовању или решили неки проблеми у понашању и учењу њихове деце, спонтане активности укључивања родитеља одликује добровољност, самомотивисаност и самоодрживост (Desforges \& Abouchaar, 2003: 84), због чега њихово проучавање побуђује посебну пажњу истраживача.

Истраживања спонтаног укључивања родитеља у образовање деце представљају прилику да се боље упознају услови за учење и развој деце у породичном окружењу и сагледа врста подршке на коју се могу ослонити ученици током школовања. Истовремено, овим истраживањима образовне установе добијају прилику да подрже родитељске компетенције кроз препознавање различитих могућности за моделовање сарадње са породицом, те креирају специфичне интервентне програме подршке родитељству, што је нарочито важно за заједнице у којима је почетак формалног школовања детета први сусрет родитеља са образовно-васпитним системом. Будући да се обухват предшколским васпитањем и образовањем у Републици Српској креће око 14\% (Ministarstvo prosvjete i kulture Republike Srpske, 2006: 7), за 
већину породица са ових простора почетак школовања детета прва је озбиљнија прилика за размену идеја о значају учења и образовања за развој детета, те улогама родитеља у том процесу.

\section{АКТИВНОСТИ УКљУЧИВАҢА РОДИТЕЉА У ОБРАЗОВАЮЕ ДЕЦЕ}

Средином деведесетих година прошлог века Џојси Епстајн (J. Epstein, 1995) је разрадила типологију укључивања родитеља у образовање деце издвајајући шест типова активности: (Тип 1) родитељство - активности родитеља и других чланова шире породице којима се деци обезбеђује сигурно и подстицајно окружење за раст, развој и учење у виду стамбене збринутости, здравствене заштите, правилне исхране, безбедности, свакодневне интеракције одраслих са децом уз стимулативне активности за учење; (Тип 2) комуникацију са школом - различите активности родитеља у оквиру двосмерне размене информација са наставним и другим особљем о актуелним догађајима у школи, савладавању програмских садржаја од стране ученика и општем напредовању детета; (Тип 3) волонтирање - укључивање родитеља у активности подршке и помоћи школским пројектима усмереним на моделовање понашања ученика или побољшање услова за учење кроз лични ангажман у учионици и другим школским активностима; (Тип 4) подршка код куће - активности којима родитељи додатно подржавају учење детета и подстичу његово напредовање разговором о школским темама, праћењем израде домаћих задатака; (Тип 5) одлучивање - укључивање родитеља у доношење одлука о питањима важним за квалитет рада школе непосредно, и преко разних органа; (Тип 6) сарадња са заједницом - ангажовање родитеља у идентификовању услуга и ресурса заједнице којима се може допринети унапређивању услова за учење за свако дете којем је подршка потребна.

Према налазима првих обимнијих емпиријских провера домета активности из типологије Епстајнове (Catsambis, 2001; McNeal, 1999, 2001), наметнуо се закључак да ниједан тип укључивања родитеља у образовање деце сам по себи није могуће директно повезати са академским напредовањем ученика, при чему је уочена позитивна веза између активности укључивања родитеља типа четири („подшка код куће“) са благим побољшањем постигнућа и значајним смањењем проблема у понашању ученика на узрасту од 14 до 18 година (McNeal, 2001: 131), те високим аспирацијама ученика и наставком школовања, без обзира на социоекономски статус породице и етничку припадност испитаника (Catsambis, 2001). 
Укључивање родитеља у образовање обезбеђивањем подршке учењу детета код куће условљено је родитељским стилом васпитања, очекивањима родитеља и њиховом спремношћу да стимулишу учење детета, те подрже завршавање школских обавеза на време, и да са децом разговарају о школи и образовању уважавајући специфичности узраста детета (Desforges \& Abouchaar, 2003). За млађу децу, на почетку школовања, од посебне важности су стимулативне активности учења у пријатној атмосфери, као и непосредна помоћ, подршка и контрола процеса овладавања школским вештинама и обавезама као што су домаћи задаци (Cooper, Lindsay \& Nye, 2000), док на адолесцентском узрасту предност имају активности које промовишу самосталност и независност детета и ослањају се на разговор и дискусију (Sanders \& Epstein, 2000; McNeal, 1999, 2001).

Када је емпиријски провераван допринос спонтаног укључивања родитеља напредовању ученика кроз интезивирање комуникације са школским особљем (Тип 2) и појачано волонтерско ангажовање родитеља у пројектима школе (Тип 3) установљено је да су, на нивоу појединог детета, користи од ових активности мале или готово никакве (Okpala, Okpala \& Smith 2001; Zellman \& Waterman, 1998).

Међутим, студије које су пратиле укључивање родитеља у образовање деце кроз ове типове активности на почетку школовања, забележиле су њихов умерен утицај на школско постигнуће ученика (Izzo et al.,1999) иако је током времена долазило до постепног пада учесталости родитељских контаката, квалитета интеракције са школским особљем и нивоа ангажовања родитеља у школи. Ово је разумљиво, будући да су родитељи на уласку детета у образовање изразито мотивисани да прикупе релевантне информације о школи и актуелним пројектима, наставном програму, атмосфери која се у школи негује, да добро упознају наставно особље и успоставе односе са њима размењујући информације о учењу и напредовању детета (Klemenović, 2014).

Такође, треба имати у виду да однос између учешћа родитеља у школским активностима и напредовања ученика вероватно није линеаран, будући да и минимално ангажовање родитеља у школи унапређује информисаност родитеља и комуникацију са школским особљем, што може повратно да делује на квалитет подршке коју родитељ обезбеђује детету код куће (Desforges \& Abouchaar, 2003). На млађим узрастима, овај мотивациони и вредносни механизам делује допуњен укључивањем родитеља у школске активности којима дете стиче вештине од значаја за школовање. 
Поставке о значају спонтаног укључивања родитеља у образовање деце на почетку школовања емпиријски су провераване у специфичном контексту Републике Српске кроз истраживање на популацији ученика првог разреда уписаној школске 2014/15. године и њихових родитеља. Специфичност образовне политике на овој териротији огледа се у чињеници да је почетак деветогодишњег основног образовања, у које се уписују деца са навршених шест година, за највећи број родитеља и деце представља први сусрет са образовно-васпитним системом.

Циљ истраживања био је испитати везу између типа активности којим се родитељи оба пола спонтано укључују у образовање своје деце, и напредовања ученика на почетку школовања израженог оствареношћу исхода учења и развоја у четири развојне сфере - физички, социо-емоционални, интелектуални, те развој говора, комуникације и стваралаштва. Претпоставка је да на почетку школовања израженије исходе учења и развоја у свим развојним сферама остварују прваци чији су очеви и мајке у комуникацији са школом и нуде разноврснију подршку напорима и интерсовањима детета у кругу породице.

Истраживање је реализовано анкетним упитником за родитеље о условима живота у породици и типичним активностима са децом у које се мајка и отац укључују код куће и у школи (скала активности укључивања родитеља у образовање деце), те скалом процене остварености исхода учења и развоја детета у четири сфере развоја.

Скала за утврђивање остварености исхода учења и развоја у четири развојне сфере конструисана је на основу мреже исхода учења за физички развој, социоемоционални, интелектуални, и развоја говора, комуникације и стваралаштва на узрасту од шест година (Спасојевић, Прибишев Белеслин и Николић, 2007). Током пилот истраживања укупно 326 индикатора сведено је на 85 ајтема разврстаних у четири супскале, који су након провере инструмента факторском анализом и методом главних оса (Principal Axis) редуковани на 55 ставки. Примена инструмента подразумевала је да се сваки од индикатора (ајтема) процењује на скали Ликертовог типа са бројевима од 1 до 5 који означавају интензитет испољавања појединог индикатора: 1 - слабо изражено, 2 - делимично слабо изражено, 3 - изражено, 4 - врло изражено и 5 - изразито изражено. Свака од скала засебно је третирана тестом за релијабилност инструмента (Табела 1) при чему су добијени коефецијенти 
унутрашње сагласности за сваку од њих који указују на то да све имају веома високу поузданост.

Табела 1. Дескриптивни подаци о поузданости скале процене исхода учења и дечјег развоја

\begin{tabular}{lcccc}
\hline \multicolumn{1}{c}{ Скала } & M & SD & бр. ајтема & $\alpha$ \\
\hline Интелектуални развој & 3,97 & 0,84 & 22 &, 98 \\
\hline Говор, комуникација и стваралаштво & 3,93 & 0,83 & 16 &, 97 \\
Социо-емоционални развој & 4,37 & 0,66 & 12 &, 95 \\
Физички и моторички развој & 4,18 & 0,85 & 5 &, 95 \\
\hline
\end{tabular}

Питања у Упитнику за родитеље конструисана су по угледу на инструмент Фантуза и сарадника (Fantuzzo, Tighe \& Child, 2000) којим се испитује породична укљученост у образовање деце (Family Involvement Questionnaire - FIQ), те упитника за испитивање успостављања односа родитеља са школом (Parent and School Survey - PASS) који је кориштен у истраживачкој студији за процену родитељске укључености урбаних и руралних породица у Хед Старт програму (Кеуs, 2014). Конструисан је упитник за родитеље са скалом од 24 ајтема којима се процењује укључивање родитеља у образовање деце. Факторском анализом која примењује методу главних оса (Principal Axis) издвојена су три фактора која објашњавају 35,65\% заједничке варијансе у вези са родитељском укључености у образовање деце: 1) АКИ - активности оријентисане на креативност и интелектуални развој детета - које обухватају укључивање родитеља у когнитивно стимулативне активности и стваралачко изражавање детета кроз игру, цртање, причање прича и сл.; 2) АШК - активности оријентисане на иколу - односе се на поступке родитеља усмерене на постављање правила у вези са навикама учења, дечјим задужењима у односу на школу, као и партнерство са школом, и 3) $\mathrm{AMO} \mathrm{-} \mathrm{активности} \mathrm{оријентисане} \mathrm{на} \mathrm{моторички} \mathrm{развој} и$ осамостаљивање - односе се на ставке у вези са условима за развој моторичких способности и подстицање дететове самосталности у обављању „дневних рутина“.

Увид у повезаност издвојених активности родитељске укључености показује да између њих постоје високе корелације, те да се ове активности најчешће јављају заједно (Табела 2). Тако на пример, родитељи који са својом децом чешће проводе време у читању, причању прича и цртању, тј. у активностима које подстичу дечју интелигенцију и креативне потенцијале, 
подржавају и општи моторички развој детета и његово осамостаљивање будући да подстичу дете да се самостално облачи, обавља личну хигијену, брине о себи и својим стварима.

Табела 2. Корелације између активности којима се родитељи укључују у образовање деце

\begin{tabular}{lccc}
\hline \multicolumn{1}{c}{ Тип активности } & АКИ & АШК & АМО \\
\hline АКИ - активности оријентисане на креативност & & & \\
и интелектуални развој детета & 1 &, 62 &, 59 \\
АШК - активности оријентисане на школу & & 1 &, 60 \\
АМО - активности оријентисане на моторички & & 1 \\
развој и осамостаљивање детета & & \\
\hline
\end{tabular}

Накнадном интервенцијом у оквиру упитника за родитеље изостављене су из скале за процену укњучености родитеља у образовање деце две ставке са релативно уједначеним оптерећењем на више фактора и још две за које се показало да не остварују значајно оптерећење ни на једном фактору. И поред смањења укупног броја ајтема на 20 може се констатовати да скалу родитељске укључености одликује задовољавајућа поузданост имајући у виду број ајтема по скали (Табеле 3).

Табела 3. Дескриптивни подаци о поузданости скале родитељске укључености

\begin{tabular}{lcccc}
\hline \multicolumn{1}{c}{ Скала } & $\mathrm{M}$ & $\mathrm{SD}$ & бр. ставки & $\alpha$ \\
\hline АКИ - активности оријентисане на креативност & 3,84 & 0,59 & 9 &, 83 \\
и интелектуални развој детета & & & & \\
АШК - активности оријентисане на школу & 4,03 & 0,55 & 7 &, 75 \\
АМО - активности оријентисане на моторички & 4,54 & 0,46 & 4 &, 67 \\
развој и осамостаљивање детета & & & & \\
\hline
\end{tabular}

У узорак истраживања ушло је укупно 1439 родитеља и исто толико шестогодишњака (706 девојчица и 733 дечака) из 14 општина са ширег подручја Републике Српске који су уписани у први разред школске 2014/15 године у 12 градских и 6 сеоских школа од којих готово две трећине (907 деце) предходно није похађало ни један облик предшколског васпитања и образовања.

Након прикупљања података и њиховог уноса у информатички програм SPSS13 (Statistical Package for Social Sciences) примењена су израчунавања основних мера дескриптивне (аритметичке средине, стандардне девијације, Пирсонов коефицијент) и инференцијалне статистике (факторска анализа, мултиваријатна анализа варијансе). 


\section{РЕЗУЛТАТИ ИСТРАЖИВАЬА ${ }^{1}$}

Анализа дескриптивних показатеља за типове активности којима се родитељи укључују у образовање деце на почетку школовања (График 1) показала је да се у Републици Српској родитељи највише укључују кроз активности оријентисане на моторички развој и осамостаљивање детета $\left(\mathrm{M}_{\mathrm{AmO}}=4,54\right)$, затим кроз активности оријентисане на школу $\left(\mathrm{M}_{\mathrm{Aш \kappa}}=4,03\right)$, а потом и кроз активности које су усмерене на креативност и интелектуални развој детета $\left(\mathrm{M}_{\mathrm{A \kappa и}}=3,84\right)$. Иако уочавамо правилност у понашању родитеља у погледу посвећености родитељској улози, извесне разлике постоје у погледу самопроцене родитељске укључености од стране мајки, с једне стране, и очева са друге.

График 1. Аритметичке средине активности којима се родитељи укључују у образовање деце на почетку школовања, укупно за родитеље, посебно за мајке и посебно за очеве

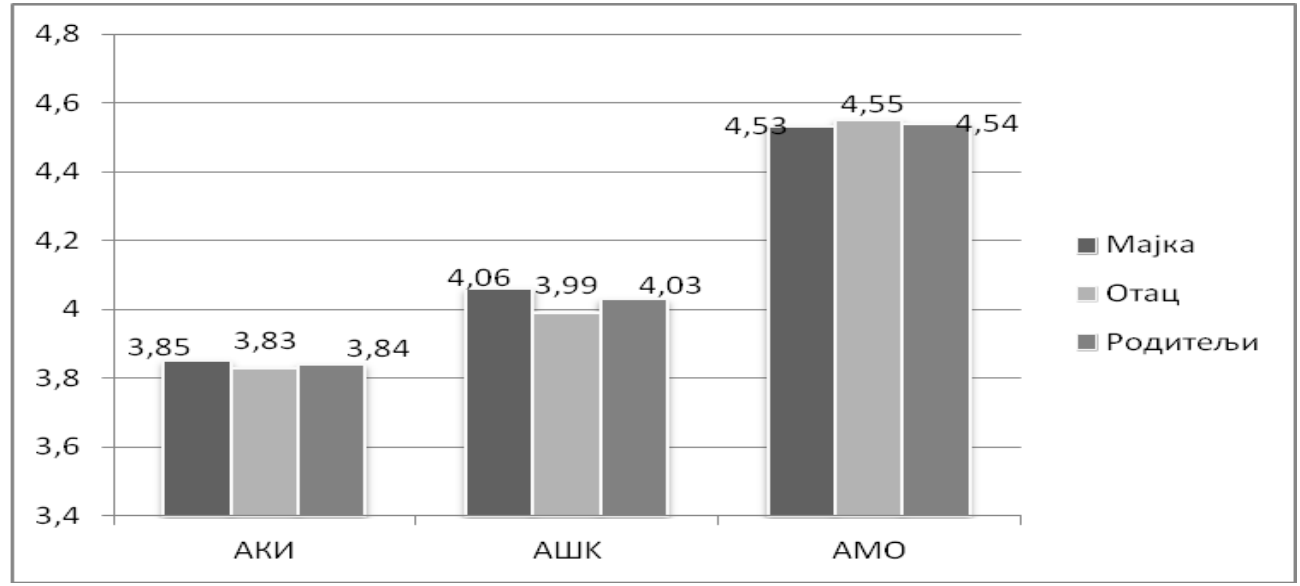

Легенда: АКИ - активности оријентисане на креативност и интелектуални развој детета; АШК - активности оријентисане на школу; $А M O-$ активности оријентисане на моторички развој и осамостаљивање детета.

Тестирање разлика према полу у самопроцени димензија родитељске укључености применом мултиваријатне анализе варијансе (МАНОВА), показало је да је ефекат пола родитеља маргинално значајан $(\mathrm{F}(3,1435)=2,50$;

1 У раду су коришћени подаци из истраживања реализованог за потребе израде докторске дисретације „Предшколски програм у Републици Српској као чинилац учења и развоја дјеце“, која је одбрањена на Филозофском факултету у Новом Саду у јулу 2016. године. 
$(\mathrm{p}=, 058))$ изузев у случају самопроцене активности оријентисаних на школу (Табела 4), будући да мајке процењују да су више укључене у овај тип активности (Мж=4,06; $\mathrm{SD}=0,02)$, него што то процењују очеви (Мм= 3,99; $\mathrm{SD}=0,02)$.

Табела 4. Укљученост очева и мајки у типове активности: униваријатни ефекти

\begin{tabular}{clcc}
\hline Предиктор & Критеријуми & $F(1,1390)$ & $p$ \\
\hline \multirow{2}{*}{ Пол } & Активности оријентисане на креативност и & 0,47 & \multirow{2}{*}{493} \\
родитеља & интелектуални развој детета (АКИ) & & \\
& Активности оријентисане на школу (АШ) & 5,83 & $\mathbf{, 0 1 6}$ \\
& Активности оријентисане на моторику & 0,03 &, 860 \\
\hline
\end{tabular}

У циљу испитивања ефеката пола родитеља и родитељске укључености на аспекте развоја деце, примењена је мултиваријатна анализа варијансе (МАНОВА). У овој анализи варијабле су биле пол родитеља и скорови на димензијама родитељске укључености, а критеријуми су били скорови на четири супскале развоја детета (физички, интелектуални, социоемоционални и развој говора, комуникације и стваралаштва). Од варијабли које се односе на родитељску укљученост, значајне ефекте на све аспекте развоја и учење детета остварују активности оријентисане на креативност и интелектуални развој (АКИ).

Да би се испитао смер повезаности родитељске укључености на исходе развоја детета, израчунати су нестандардизовани парцијални доприноси (бете) димензија родитељске укључености (Табела 5). Резултати показују да је већа укљученост родитеља у активности оријентисане на кретивност и интелектуални развој у позитивној корелацији са израженијим исходима учења и развоја не само из сфере интелектуалног развоја већ и свих других развојних сфера. Важно је напоменути да ефекат ове врсте родитељске укључености не зависи од пола родитеља, тј. укљученост и очева и мајки у активности оријентисане на креативност и интелектуални развој подједнако доприноси напредовању деце на почетку школовања. 
Табела 5. Парцијални доприноси активности оријентисане на креативност и интелектуални развој у предикцији развоја детета према развојним сферама

\begin{tabular}{cllllc}
\hline Варијабла & \multicolumn{1}{c}{ Критеријуми } & $B$ & $S E$ & $t$ & $p$ \\
\hline Активности & интелектуални развој & 0,44 & 0,07 & 6,37 &, 000 \\
оријентисане & говор, комуникација и & 0,39 & 0,07 & 5,76 &, 000 \\
на креативност & $\begin{array}{l}\text { стваралаштво } \\
\text { социо-емоционални развој } \\
\text { и }\end{array}$ & 0,26 & 0,06 & 4,61 & ,000 \\
$\begin{array}{c}\text { интелектуални } \\
\text { развој (АКИ) }\end{array}$ & & 0,41 & 0,07 & 5,69 & ,000 \\
\hline
\end{tabular}

Преостала два типа активности родитељске укључености остварују ефекат у интеракцији са полом родитеља. Наиме, интеракција пола родитеља и активности оријентисаних на школу (АШК) остварује ефекат на развој говора, комуникације и стваралаштва и социо-емоционални развој деце, док је ефекат на моторички развој и осамостаљивање маргинално значајан. Позитиван ефекат указује на то да укљученост мајке у активности оријентисане на школу више доприноси развоју комуникације и стваралаштва, социо-емоционалном развоју и маргинално физичком и моторичком развоју (Табела 6). Маргинално значајан униваријанти ефекат интеракције на интелектуални развој у овој анализи није се потврдио, те се може закључити да интелектуални развој детета боље подржава родитељска укљученост у активности оријентисане на креативност али и на школу, и то без обзира на пол родитеља.

Табела 6. Парцијални доприноси активности оријентисане на школу у предикцији развоја детета према развојним сферама

\begin{tabular}{|c|c|c|c|c|c|}
\hline Варијабла & Критеријуми & $B$ & $S E$ & $t$ & $p$ \\
\hline \multirow{4}{*}{$\begin{array}{c}\text { Пол родитеља х } \\
\text { Активности } \\
\text { оријентисане } \\
\text { на школу (АШК) }\end{array}$} & интелектуални развој & 0,15 & 0,10 & 1,50 & ,133 \\
\hline & $\begin{array}{l}\text { говор, комуникација и } \\
\text { стваралаштво }\end{array}$ & 0,21 & 0,10 & 2,07 & 038, \\
\hline & социо-емоционални развој & 0,22 & 0,08 & 2,72 & ,007 \\
\hline & физички и моторички развој & 0,19 & 0,10 & 1,91 & 056 \\
\hline
\end{tabular}

У случају интеракције пола родитеља и активности оријентисаних на моторички развој и осамостаљивање детета (AMO) добијени су резултати који указују на значајан ефекат ове варијабле на све аспекте развоја детета (Табела 7). Негативни ефекти указују на то да је очева укљученост у активности оријентисане на моторички развој и осамостаљивање значајније доприноси свим аспектима развоја детета. 
Табела 7. Парцијални доприноси активности оријентисане на моторику у предикцији развоја детета према развојним сферама

\begin{tabular}{clcccc}
\hline Варијабла & \multicolumn{1}{c}{ Критеријуми } & $B$ & $S E$ & $t$ & $p$ \\
\hline & интелектуални развој & $-0,26$ & 0,11 & - &, 022 \\
$\begin{array}{l}\text { Пол родитеља х } \\
\text { Активности } \\
\text { оријентисане }\end{array}$ & $\begin{array}{l}\text { говор, комуникација и } \\
\text { стваралаштво }\end{array}$ & $-0,32$ & 0,11 & - &, 004 \\
$\begin{array}{l}\text { на моторику } \\
\text { (АМО) }\end{array}$ & $\begin{array}{l}\text { социо-емоционални развој } \\
\text { физички и моторички }\end{array}$ & $-0,20$ & 0,09 & - &, 025 \\
& развој & $-0,27$ & 0,11 & - &, 019 \\
& & & & 2,35 & \\
\hline
\end{tabular}

\section{ДИСКУСИЈА}

Преглед резултата истраживања обављеног на територији Републике Српске потврђује тенденције и везе уочене и у другим студијама између спонтаног укључивања родитеља у образовање деце и напредовања ученика на почетку школовања (Fantuzzo et al., 2000; Davis-Kean, 2005; Collins et al., 2000; Christenson \& Sheridan, 2001; Izzo et al., 1999). Наиме, скорови на све четири супскале дечјег развоја и учења (физичког, интелектуалног, социоемоционалног и развоја говора, комуникације и стваралаштва) најизраженији су код ученика првог разреда чији се родитељи интезивније укључују у образовање деце кроз активности оријентисане на подстицање креативности и интелектуалног развоја (АКИ) причањем прича, читањем и цртањем са децом. Укључивање родитеља у активности оријентисане на школу (АШК), исказано кроз подршку учењу и извршавању школских обавеза, разговором о школским темама те сарадњом са школом, показало је значајнију позитивну корелацију само са напредовањем ученика у сфери интелектуалног развоја.

Запажена је такође, позитивна веза између веће укључености мајки у активности оријентисане на школу (АКИ) и напредка ученика првог разреда у сфери развоја говора, комуникације и стваралаштва, те социо-емоционалном аспекту развоја. С друге стране, већа укљученост очева у активности оријентисане на моторички развој и подршку осамостаљивању детета у позитивној вези је са напредовањем ученика у свим развојним сферама. Уочене тенденције на трагу су студија које истичу развојни значај веће укључености очева у васпитање деце (Dubowitz et al., 2001; Sarkadi et al, 2008), описујући интеракцију очева са децом чешће као телесну и моторички активнију у односу на вербално обликовану интеракцију мајки са децом на предшколском (Winsler et al., 2005) и млађем школском узрасту. 


\section{ЗАКЉУЧАК}

На основу представљених налаза истраживања, и резултата истраживачких студија других аутора, могло би се закључити да су родитељска подршка детету код куће, партнерска комуникација са школом и учешће родитеља у школским активностима, најзаступљенији типови активности спонтаног укључивања родитеља у образовање деце на почетку школовања који имају умерене позитивне ефекте на учење и напредовање ученика, при чему је нешто израженији допринос родитељске подршке детету код куће у односу на друга два типа (Christenson \& Sheridan, 2001; Izzo et al., 1999).

На почетку школовања боље напредују и више успеха у учењу имају ученици чији се родитељи у свакодневној интеракцији са њима у кругу породице, ослањају на (раз)говор као средство подршке и решавања проблема, како у школским тако и практичним и игровиним ситуацијама, нудећи цртање, писање, причање прича и читање као средство за сређивање дечјег искуства (Bracken \& Fischel 2008; Yeung, Linver \& Brooks-Gunn 2002). Иако су позитивни ефекти ових активности укучивања мајки у образовање деце већ деценијама у назад описани у литератури, новија истраживања истичу развојни значај веће укључености очева у васпитање и образовање деце од најранијег узраста (Dubowitz et al., 2001; Sarkadi et al., 2008; Sirridge, 2001) посебно њиховог ангажовања у активностима причања и читања прича (Baker, 2013; Clark, 2009).

Боље познавање утицаја породице, посебно ефеката укључивања родитеља у образовне активности са децом у породици и школи, од посебног је значаја за све који су професионално усмерени на васпитање и образовање деце и младих. Спонтано укључивање родитеља у образовање детета може имати много већи утицај на дечји развој и учење у односу на друге факторе будући да родитељско учешће у функцију ставља интегрисане ресурсе породице, школе и шире заједнице (Desforges \& Abouchaar, 2003; Epstein et al. 2002; Westmoreland, 2009). Притом је важно имати у виду да карактеристике образовно система и култура образовно-васпитне установе обликују прилике за укључивање родитеља у активности којима се обезбеђују повољнији услови за учење све деце и развијају сараднички односи на релацији школа породица, док је на развој родитељских компетенција очева и мајки потребно деловати већ од рођења детета кроз системски организовану друштвену подршку породицама са децом. 
Јасмина У. Клеменовић, Наташа Цвијановић

\section{EXAMINATION OF SPONTANEOUS INVOLVEMENT OF PARENTS IN EDUCATION OF CHILDREN AT THE BEGINNING OF SCHOOLING}

\section{Summary}

The paper focuses on examining the various types of activities of parents who are involved in the education of children, and their impact on the progress of pupils at the beginning of their schooling. The survey examined 1,439 first-grade pupils and their parents from the territory of the Republic of Srpska. The questionnaire for the parents examined the representation of different types of activities within the family and in communication with the school, while the progress of pupils at the beginning of schooling was monitored by the assessment scale of the achievement of learning outcomes and development in the four spheres of development. It turned out that the most spontaneous activities involving parents were directed towards the independence of children and support to their motor development, then towards overcoming the school tasks and responsibilities, and finally through activities oriented to the creativity and intellectual development of the child. In addition, the involvement of mothers in the school-oriented activities was positively related to the advancement of pupils in the sphere of intellectual development, as well as the development of speech, communication and creativity, while the involvement of fathers in motor activities and the independence of children was in a positive correlation with the advancement of pupils in all the spheres of development. It is necessary to strengthen the parents' awareness of the importance of their involvement in the education of children through different types of activities from the earliest childhood, and especially during the first years of schooling, in which all educational institutions have a key role.

Keywords: involvement of parents in education of children, support for children's learning at home, family and school cooperation, pupils' progress at the beginning of schooling. 


\section{ЛИТЕРАТУРА}

Baker, C. E. (2013). Fathers' and Mothers' Home Literacy Involvement and Children's Cognitive and Social Emotional Development: Implications for Family Literacy Programs. Applied Developmental Science, 17(4), 184-197.

Bracken, S. S., \& Fischel, J. E. (2008). Family reading behavior and early literacy skills in preschool children from low-income backgrounds. Early Education and Development, 19(1), 45-67.

Carter, S. (2002). The Impact of Parent/Family Involvement on Student Outcomes: An Annotated Bibliography of Research from the Past Decade. The Consortium for Appropriate Dispute Resolution in Special Education CADRE. ED476296

Catsambis, S. (2001). Expanding knowledge of parental involvement in children's secondary education: connections with high schools seniors' academic success, Social Psychology of Education,5, 149-177.

Christenson, S. L., \& Sheridan, S. M. (2001). Schools and families: Creating essential connections for learning. New York: Guilford Press.

Clark, C. (2009). Why fathers matter to their children's literacy. London: National Literacy Trust. Preuzeto 5. oktobra 2016, sa http:// www.files.eric.ed.gov/fulltext/ ED513437

Collins, W. A., Maccoby, E. E., Steinberg, L., Hetherington, E. M., \& Bornstein, M. H. (2000). Contemporary Research on Parenting: The Case for Nature and Nurture. American Psychologist, 55(2), 218-232.

Cooper, H. M., Lindsay, J. J., \& Nye, B. (2000). Homework in the home: How student, family, and parenting-style differences relate to the homework process. Contemporary Educational Psychology, 25(4), 464-87.

Davis-Kean, P. E. (2005). The Influence of Parent Education and Family Income on Child Achievement: The Indirect Role of Parental Expectations and the Home Environment. Journal of Family Psychology, 19(2), 294-304.

Desforges C., \& Abouchaar, A., (2003). The Impact of Parental Involvement, Parental Support and Family Education on Pupil Achievement and Adjustment: A Literature Review. DfES Research Report 433. Preuzeto 5. oktobra 2016, sa http://library.bsl.org.au/jspui/ bitstream/1/3644

Drake, D. D. (2000). Parents and families as partners in the education process: Collaboration for the success of students in public schools. ERS Spectrum, 18(2), 34-39. EJ609580.

Dubowitz, H., ... \& Runyan, D. (2001). Father involvmenet and child functioning at age 6 years: a multisite study. Child Maltreat, 6, 300-309. 
Epstein, J. L. (1995). School/family/community partnerships: Caring for the children we share. Phi Delta Kappan, 701-712.

Epstein, J. L., ... \& Frances L. (2002). School, Family, and Community Partnerships: Your Handbook for Action.Washington: Office of Educational Research and Improvement

Fantuzzo, J., Tighe, E., \& Child, S. (2000). Family Involvement Questionnaire: A Multivariate Assessment of Family Participation in Early Childhood Education. Journal of Educational Psychology, 92(2), 367-376.

Izzo, C.V., Weissberg, R. P., Kasprow, W. J., \& Fendrich, M. (1999). A longitudinal assessment of teacher perceptions of parent involvement in children's education and school performance. American Journal of Community Psychology, 27, 817-39.

Keys, A. (2014). Family Engagement in Rural and Urban Head Start Families: An Exploratory Study. Early Childhood Education Journal, doi: 10.1007/s10643-014- 0643-8

Klemenović, J. (2014). Spremnost za školu u inkluzivnom kontekstu. Novi Sad: Filozofski fakultet Univerziteta u Novom Sadu.

McNeal, R.B. (2001). Differential effects of parental involvement on cognitive and behavioural outcomes by socioeconomic status. Journal of SocioEconomics, 30, 171-179.

Ministarstvo prosvjete i kulture Republike Srpske (2006). Osnove programa predškolskog vaspitanja i obrazovanja- eksperimentalna verzija. Banja Luka: Ministarstvo prosvjete i kulture Republike Srpske. (ćirililica)

Okpala, C. O., Okpala, A. O., \& Smith, F. E. (2001). Parental involvement, instructional expenditures, family socioeconomic attributes, and student achievement. The Journal of Educational Research, 95(2), 110-115.

Sanders, M. G., \& Epstein, J. L. (2000). Building school-family-community partnerships in middle and high school. In M G. Sanders (Ed.), School students placed at risk: Research, policy, and practice in the education of poor and minority adolescents. Mahwah : Lawrence Erlbaum Associates. 339-61.

Sarkadi, A., Kristiansson, R., Oberklaid, F., \& Bremberg, S. (2008). Fathers' involvement and children's developmental outcomes: A systematic review of longitudinal studies. Acta Paediatrica, 97, 153-158.

Simon, B. S. (2001). Family involvement in high school: Predictors and effects. NASSP Bulletin, 85(627), 8-19. 
Spasojević, P., Pribišev Beleslin, T. i Nikolić, S. (2007). Program predškolskog vaspitanja $i$ obrazovanja. Ministarstvo prosvjete i kulture Republike Srpske: Zavod za udžbenike i nastavna sredstva. (ćirililica)

Westmoreland, H., Bouffard, S., O'Carroll, K., \& Rosenberg, H. (2009). Data collection instruments for evaluating family involvement. Preuzeto 5. oktobra 2016, sa http://www.hfrp.org.

Winsler, A., Madigan, A. L., \& Aquilino, S. A. (2005). Correspondence between maternal and paternal parenting styles in early childhood. Early Childhood Research Quarterly, 20, 1-12.

Yeung, W. J., Linver, M. R., \& Brooks-Gunn, J. (2002). How money matters for young children's development: Parental investment and family processes. Child Development, 73(6), 1861-1879.

Zellman, G. L., \& Waterman, J. M. (1998). Understanding the impact of parent school involvement on children's educational outcome. The Journal of Educational Research, 91 (6), 370-380. 